\title{
Cytological diversity in colchiploid of Pontianak tangerine citrus
}

\author{
Farida Yulianti*, and Dita Agisimanto \\ Indonesian Citrus and Subtropical Fruits Research Institute, Jl. Raya Tlekung no 1, Junrejo, Batu, \\ East Java, Indonesia
}

\begin{abstract}
Pontianak tangerine citrus (Siam Pontianak) is the most popular tangerine citrus in Indonesia. Induced mutation with colchicine treatment on Pontianak tangerine was intended to produce polyploid plants. The study aimed to analyze the cytological diversity in colchiploid of Pontianak tangerine citrus. The study was conducted at ICISFRI from January - May 2018. The cytological analysis was performed on a five-year-old of 36 colchiploids of Pontianak tangerine and a mother plant as control. The results showed that the colchiploid plants had higher chromosome numbers, stomatal sizes, and chloroplast numbers than the control. However, the stomatal density in several genotypes did not differ from that of the control. Colchicine treatment resulted in an aneuploid plant with chromosome number $18+x$. Based on the clustering analysis results, all colchiploid plants differed from the control with a variability coefficient of 0.65 . The colchiploid plants were not grouped according to colchicine concentration and duration of treatment. The increase of colchicine concentration and treatment duration did not correlate with the increasing ploidy number of colchiploid plants. The implication of the research result was the stomatal density, stomatal size, and chloroplast number were useful tools for rapid pre-screening of plant polyploidy.
\end{abstract}

\section{Introduction}

Pontianak tangerine citrus is the most popular tangerine citrus in Indonesia. It is the preferred type of citrus fruit for those Indonesian consumers. It was released in 2003, based on the Decree of the Minister of Agriculture No.466/Kpts/PD.210/9/2003. The fruit is round in shape with a flat blunt end. The peel of the fruit is thin $(1-1.5 \mathrm{~mm})$, squishy, and attached slightly to the fruit segment. The albedo is thin and quite brittle, so it is often attached to the fruit segment. This fruit peel condition caused this fruit to be more difficult to open and split.

The Pontianak tangerine citrus fruit quality improvement has been carried out by the Indonesian Citrus and Subtropical Fruits Research Institute (ICISFRI) through in vitro induced mutation by colchicine. The induced mutation was carried out on Pontianak tangerine callus with the colchicine dosage $0.05 \%, 0.10 \%$, and $0.15 \%$, and the duration of treatment was 1 to 10 days. The genetic selection was carried out on the plantlets. The

* Corresponding author: adiraf212@gmail.com 
selected plantlets were grafted on the Japansche Citroen (JC) rootstock. The treatment had a significant effect on leaf shape, fruit skin color, fruit size, and skin thickness [1].

The characters changing of Pontianak tangerine citrus are thought to be caused by polyploidization as a result of colchicine treatment. Polyploidization is one of the methods used to duplicate plant chromosomes to improve the quality of plants such as better plant vigour, larger flowers [2-4], larger fruits [5,6], larger leaves, darker green color, thicker leaves $[3,4,6]$ and better tolerance to abiotic pressure [6]. Colchicine is a widely used as a mitotic inhibitor for the induction of polyploidy in plants during their cell division by inhibiting the chromosome segregation $[2,7,8]$.

Confirmation of ploidy level status is an important step for the successful utilization of synthetic polyploids. The methods for the detection of polyploidy are categorized as direct and indirect. Direct methods are more accurate than indirect methods, that involve chromosome counting and measuring nuclear genome by flow cytometry (FCM). In contrary to direct methods, indirect methods involve physiological, morphological, and anatomical traits that are preferably due to rapid and simple [8]. Anatomical assessment engrosses stomatal frequency and size as well as chloroplast density in guard cells [9]. The measurement of stomatal dimensions is rapid, inexpensive, non-destructive, does not require expensive equipment, and has a fairly high accuracy rate [10]. The aim of the study was to analyze the cytological diversity in colchiploid of Pontianak tangerine citrus through direct and indirect methods.

\section{Material and methods}

\subsection{Plant materials}

The cytological analysis was performed on five-year-old of thirty-six colchiploids of Pontianak tangerine and one mother plant as a control (Table 1). All the samples were collected from plants that growing in experimental field of IPPTP Tlekung of ICISFRI.

Table 1. The genotypes were observed in the study.

\begin{tabular}{|c|l|c|c|c|c|c|c|}
\hline No & Genotypes & $\begin{array}{c}\text { Concentration } \\
\text { of Colchicine } \\
(\%)\end{array}$ & $\begin{array}{c}\text { Duration of } \\
\text { Treatment } \\
\text { (Days) }\end{array}$ & No & Genotypes & $\begin{array}{c}\text { Concentration } \\
\text { of Colchicine } \\
\text { (\%) }\end{array}$ & $\begin{array}{c}\text { Duration of } \\
\text { Treatment } \\
\text { (Days) }\end{array}$ \\
\hline 1 & $\mathrm{c} 051 \# 1$ & 0.05 & 1 & 20 & $\mathrm{c} 157 \# 11$ & 0.15 & 7 \\
\hline 2 & $\mathrm{c} 051 \# 3$ & 0.05 & 1 & 21 & $\mathrm{c} 1510 \# 2$ & 0.15 & 10 \\
\hline 3 & $\mathrm{c} 053 \# 3$ & 0.05 & 3 & 22 & $\mathrm{c} 1510 \# 3$ & 0.15 & 10 \\
\hline 4 & $\mathrm{c} 0510 \# 2$ & 0.05 & 10 & 23 & $\mathrm{c} 1510 \# 4$ & 0.15 & 10 \\
\hline 5 & $\mathrm{c} 0510 \# 3$ & 0.05 & 10 & 24 & $\mathrm{c} 1510 \# 6$ & 0.15 & 10 \\
\hline 6 & $\mathrm{c} 102 \# 1$ & 0.1 & 2 & 25 & $\mathrm{c} 1510 \# 7$ & 0.15 & 10 \\
\hline 7 & $\mathrm{c} 102 \# 2$ & 0.1 & 2 & 26 & $\mathrm{c} 1510 \# 11$ & 0.15 & 10 \\
\hline 8 & $\mathrm{c} 105 \# 1$ & 0.1 & 5 & 27 & $\mathrm{c} 1510 \# 12$ & 0.15 & 10 \\
\hline 9 & $\mathrm{c} 105 \# 2$ & 0.1 & 5 & 28 & $\mathrm{c} 1510 \# 13$ & 0.15 & 10 \\
\hline 10 & $\mathrm{c} 155 \# 1$ & 0.15 & 5 & 29 & $\mathrm{c} 1510 \# 17$ & 0.15 & 10 \\
\hline 11 & $\mathrm{c} 155 \# 4$ & 0.15 & 5 & 30 & $\mathrm{c} 1510 \# 18$ & 0.15 & 10 \\
\hline 12 & $\mathrm{c} 155 \# 10$ & 0.15 & 5 & 31 & $\mathrm{c} 1510 \# 20$ & 0.15 & 10 \\
\hline 13 & $\mathrm{c} 155 \# 12$ & 0.15 & 5 & 32 & $\mathrm{c} 1510 \# 21$ & 0.15 & 10 \\
\hline 14 & $\mathrm{c} 155 \# 13$ & 0.15 & 5 & 33 & $\mathrm{c} 1510 \# 24$ & 0.15 & 10 \\
\hline 15 & $\mathrm{c} 155 \# 14$ & 0.15 & 5 & 34 & $\mathrm{c} 1510 \# 25$ & 0.15 & 10 \\
\hline 16 & $\mathrm{c} 157 \# 3$ & 0.15 & 7 & 35 & $\mathrm{c} 1510 \# 27$ & 0.15 & 10 \\
\hline 17 & $\mathrm{c} 157 \# 4$ & 0.15 & 7 & 36 & $\mathrm{c} 1510 \# 28$ & 0.15 & 10 \\
\hline 18 & $\mathrm{c} 157 \# 7$ & 0.15 & 7 & 37 & Control & 0 & 0 \\
\hline 19 & $\mathrm{c} 157 \# 8$ & 0.15 & 7 & & & & \\
\hline
\end{tabular}




\subsection{Chromosome observations}

At first, the shoot tips were soaked in $45 \%$ glacial acetic acid for at least $15 \mathrm{~min}$ at $5{ }^{\circ} \mathrm{C}$ and then washed with aquadest three times. The fixative samples were soaked in $\mathrm{KCl} 1 \mathrm{~N}$ for at least $50 \mathrm{~min}$ at $50{ }^{\circ} \mathrm{C}$ and then washed with aquadest three times. The macerated samples were stained with $2 \%$ aceto-orcein by soaking at least $15 \mathrm{~min}$ at room temperature. The very small shoot tip was cut off with a clean scalpel placed on the squeezed-out tissue and the edge of the previous coverslip, then tapped gently with a pencil. The excess liquid was immediately removed with filter paper by gently pressing the coverslip without moving it [11]. The number of chromosomes was counted under a trinocular microscope (Olympus$\mathrm{BX} 51)$ at 1000x magnification.

\subsection{Stomatal observations}

Stomatal observations were conducted in the morning (08.00 AM) when leaf stomata were expected to remain open. Mature healthy leaves samples were used from the third to fourth nodes of the primary branches. The leaves were cleaned and a small part of the leaf surface from the lower (abaxial) epidermis was sampled using a thin layer of transparent nail polish. The prepared sample was left for about 10 minutes to dry and the nail polish impression was swiftly removed using a transparent adhesive tape [12]. Then, sample was placed on an object glass slide and observed under a trinocular microscope (Olympus-BX51) at 400x magnification. The stomatal size was measured using Olympus cell Sens Standard software attached to microscopy system.

\subsection{Chloroplast observations}

Leaves as mentioned above are also used for chloroplast observation. The lower epidermis of individual mature leaves was peeled and placed on an object-glass slide and stained with a few drops of a $1 \%$ silver-nitrate solution [13]. The number of chloroplasts per guard cell pair was counted under a trinocular microscope (Olympus-BX51) at 400x magnification from at least 15 stomata of each of four-leaf samples.

\subsection{Data analysis}

Data analysis was performed based on the results of photographs obtained from the samples. Then the data is tabulated into an observation table and averaged. After obtaining the mean value, then it is plotted by using the PAST software version 4.05.

\section{Results and discussion}

The ploidy levels of 36 regenerated Pontianak tangerine citrus were identified by chromosome number counting. These observations showed that colchicine treatment increased the number of chromosomes, but the multiple rates of chromosome set number were different (aneuploid). Aneuploidy is defined as a chromosome number that is not an exact multiple of the usually haploid number [14], reflects both gains/losses of whole chromosomes, as well as non-balanced rearrangements of chromosomes [15]. We found that the chromosome number of the diploid control plant was $2 n=2 x=18$ and the chromosome number of colchiploid plants were varied from $20-27$ which are $12.7-47.9 \%$ higher than control (Fig. 1 - 2). 


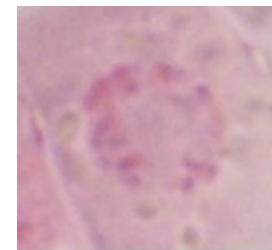

diploid

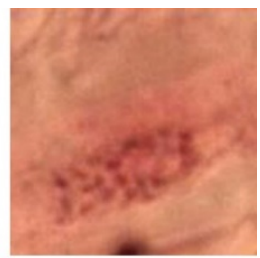

aneuploid

Fig. 1. The chromosome of diploid and aneuploid of Pontianak tangerine (1000x magnification)

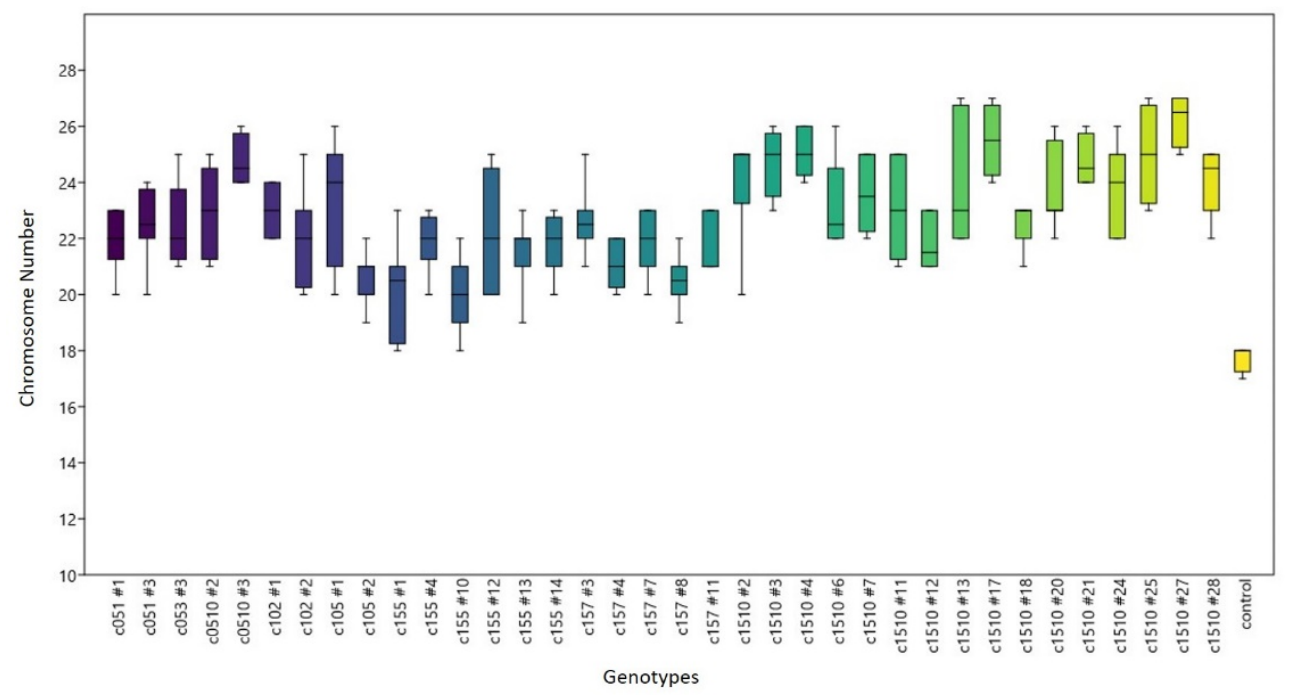

Fig. 2. Diversity of the chromosome number of colchiploid of Pontianak tangerine and control

Polyploidy is defined as the presence of more than two complete chromosome sets in a cell nucleus and is considered to be responsible for plant evolution and diversification [16]. Polyploids induced by colchicine may retain a small number of undetected chimeric cells even after regeneration. Colchicine is arrested meiosis, which is widely used because of its effectiveness, abundance, and is non-toxic to cells [7]. The mechanism of colchicine in cells has been studied since the 1950s and it was discovered that colchicine binds to tubulins (subunits of microtubule) which will prevent orientation and aggregation of the tubulin subunits into a microtubule. The failure of microtubule formation during mitosis will stop the cell cycle at metaphase. This will prevent chromosome pairs from separating and move to opposite poles during anaphase to form two sets of chromosomes before cytokinesis. The failure of cytokinesis by the end of the cell cycle will cause two sets of chromosomes to remain in a single nucleus when a polyploid cell is formed [17].

An important step in polyploidization is to determine ploidy levels in a quick and simple way to get the important information. The direct method through counting chromosomes in mitotic cells is an accurate method, but time-consuming and needs a lot of experience. Therefore, indirect methods have been developed for ploidy determination. Cytologic characteristics such as the size of stomata cells, stomata density, pollen grain diameter, and number of chloroplasts in guard cells can be used as indirect ways for determining polyploids $[8,18,19]$.

Examination of anatomical characters especially those related to stomata is an easy and reliable method to identify polyploids in comparison with diploids [19,20]. Polyploidy is commonly characterized by a stomatal density reduction, increase in stomata size, and increase in the number of guard cell chloroplast [21,22]. The results suggested that 
colchiploid plants in this study have varied stomatal density, larger stomatal size (Fig 3.), and larger chloroplast number than control (Fig. 4). However, majority of the stomatal density was indifferent statistically. The mean of the stomatal density of colchiploid plants was varied from 651-869 stomata per $\mathrm{mm}^{2}$, while the control was 773 stomata per $\mathrm{mm}^{2}$ (Fig. 5). The stomata length and width of colchiploid plants were significantly affected by colchicine treatments. The stomata length of those colchiploid plants were measured averagely ranging from 18.09 to $21.08 \mu \mathrm{m}$ while control at $9.92 \mu \mathrm{m}$. Similarly, the stomata width of those colchiploid plants were measured averagely ranging from 16.05 to $19.98 \mu \mathrm{m}$, while control at $7.62 \mu \mathrm{m}$ (Fig 6-7). The mean of chloroplast number in guard cells of colchiploid plants was varied from $17-24$ which are $13.96-53.08 \%$ higher than control (Fig. 8). Our results indicated that stomatal density, stomatal size, and chloroplast number were useful tools for rapid pre-screening of plant polyploidy. The fast-tracking chromosome number using those characters is important to get early information of mutant population.

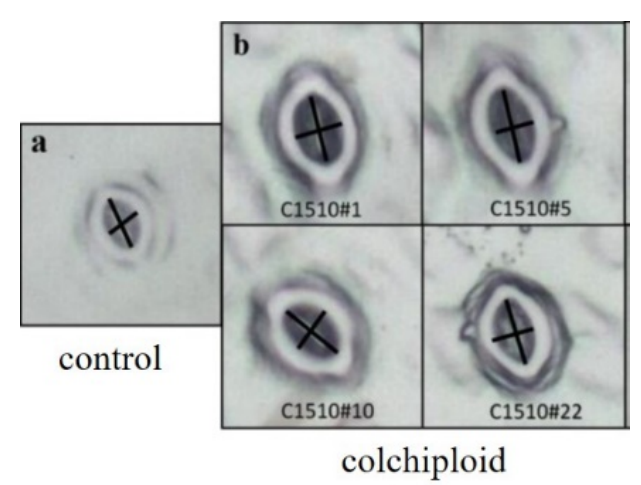

Fig. 3. The stomata of colchiploid of Pontianak tangerine and control (400x magnification)

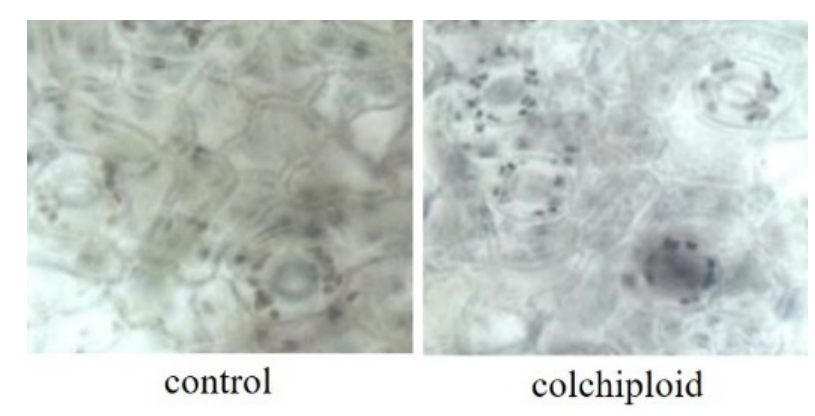

Fig.4. The chloroplast of colchiploid of Pontianak tangerine and control (400x magnification) 


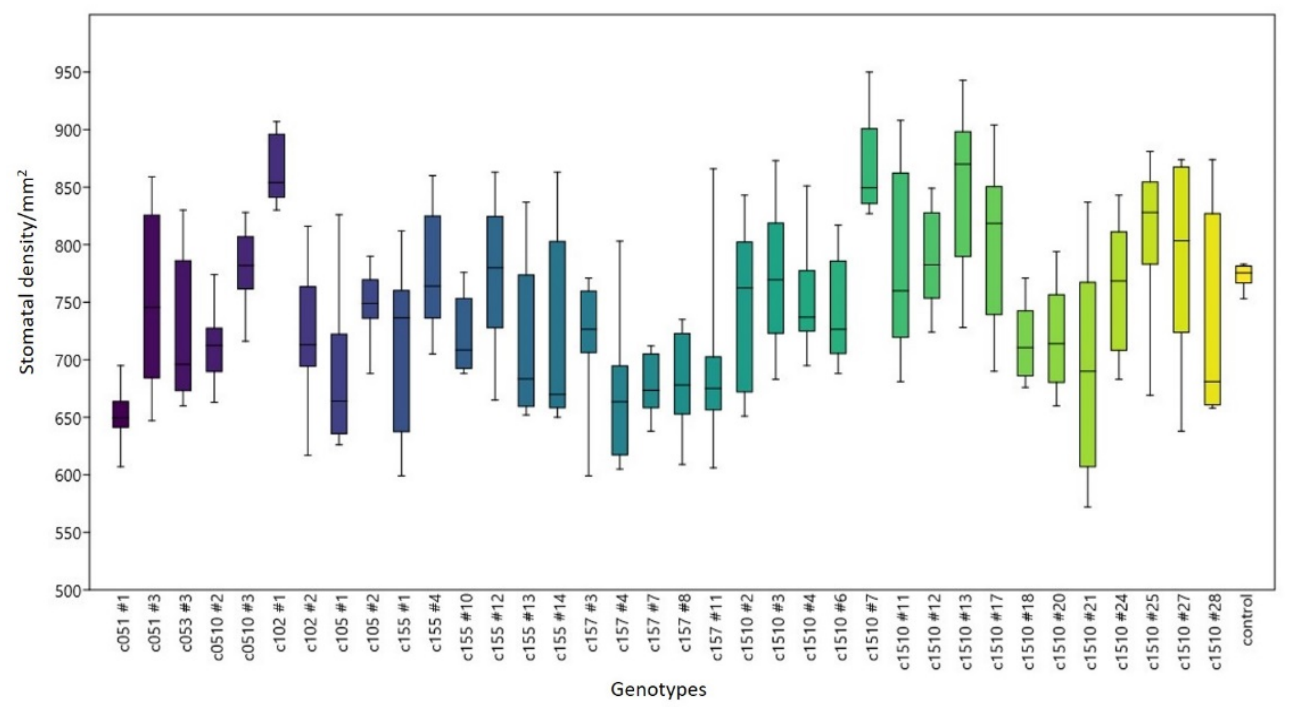

Fig. 5. Diversity of the stomatal density of colchiploid of Pontianak tangerine and control

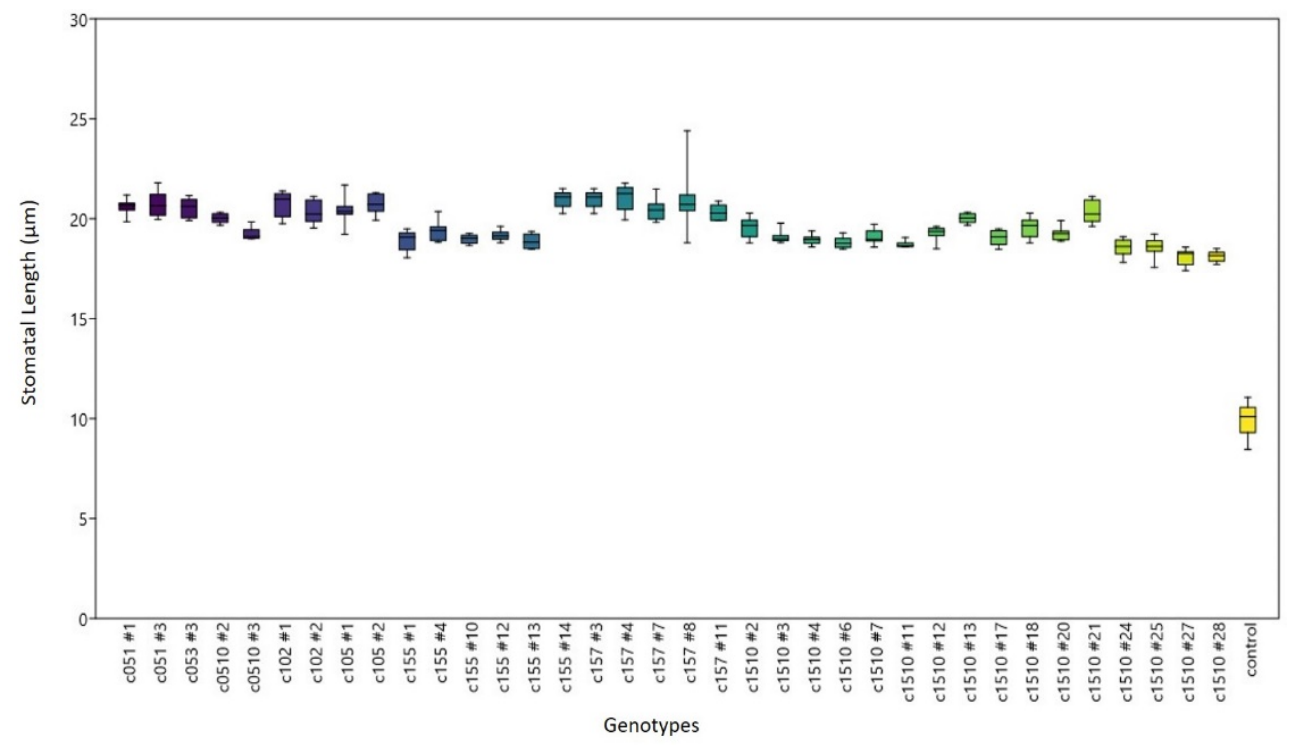

Fig. 6. Diversity of the stomatal length of colchiploid of Pontianak tangerine and control 


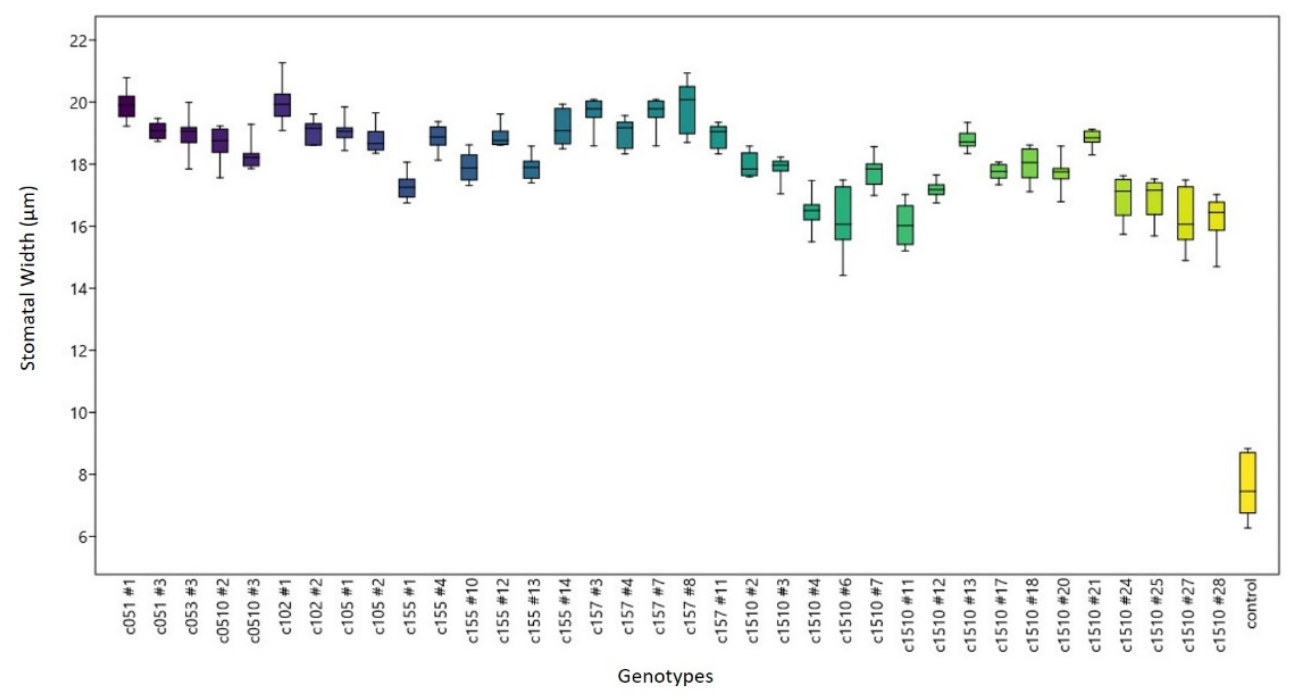

Fig. 7. Diversity of the stomatal width of colchiploid of Pontianak tangerine and control

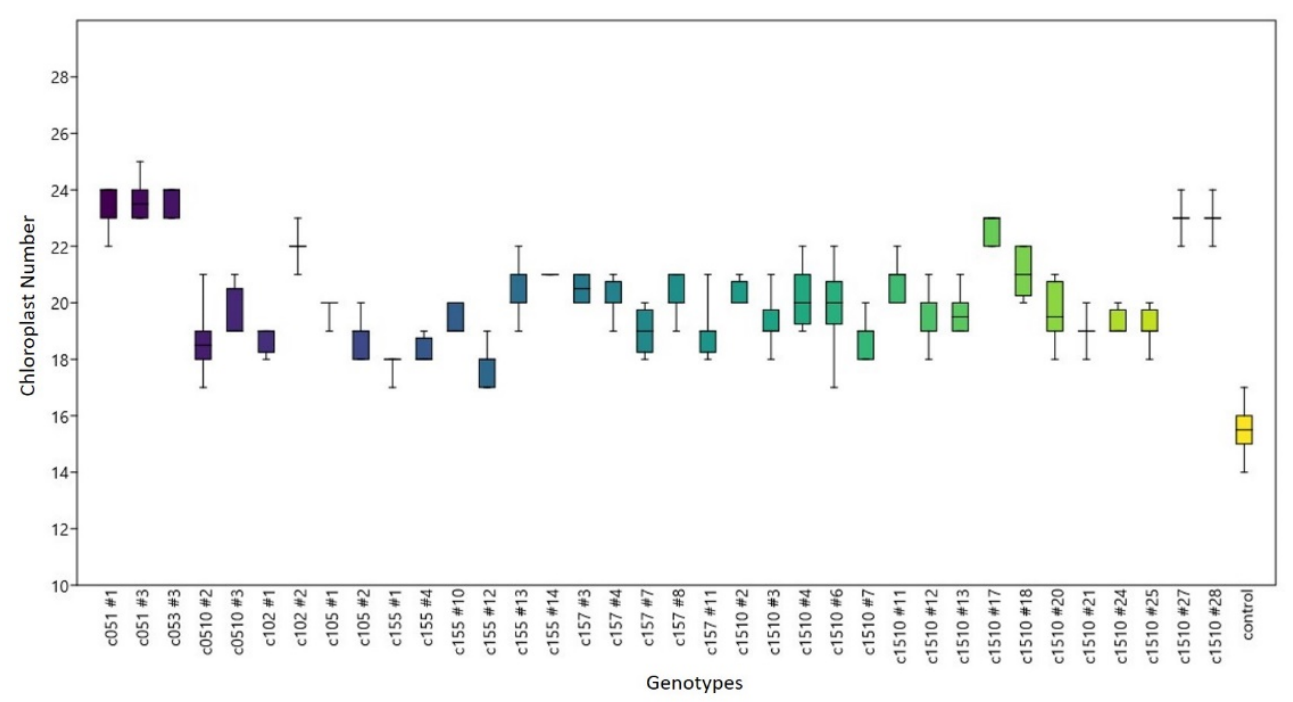

Fig. 8. Diversity of the chloroplast number of colchiploid of Pontianak tangerine and control

Based on cytological data, a variability matrix was calculated according to Gower's coefficient. Variability dendrogram was constructed using UPGMA cluster analysis (Fig. 9). Cophenetic correlation between ultra-metric similarities of tree and similarity matrix was found to be high $(\mathrm{r}=0.92, \mathrm{P}<0.01)$, suggesting that the cluster analysis strongly represents the variability matrix. The dendrogram separated the colchiploid plants from the control with a variability index of 0.65 . The colchiploid plants separated into two groups with a variability index of 0.2 . The colchiploid plants were not grouped according to colchicine concentration and duration of treatment. In other word, the increasing of colchicine concentration and duration of treatment did not corelated with the increasing of ploidy number of colchiploid plants This condition was influenced by the ability of plant cells to respond to antimitotic agents. The effectiveness of polyploidy depends on many factors, such as a well-established protocol for the multiplication of the target species, type and 
concentration of the antimitotic agent, exposure time, the method of antimitotic solution application, explant type, and regrowth medium [8,9,23].

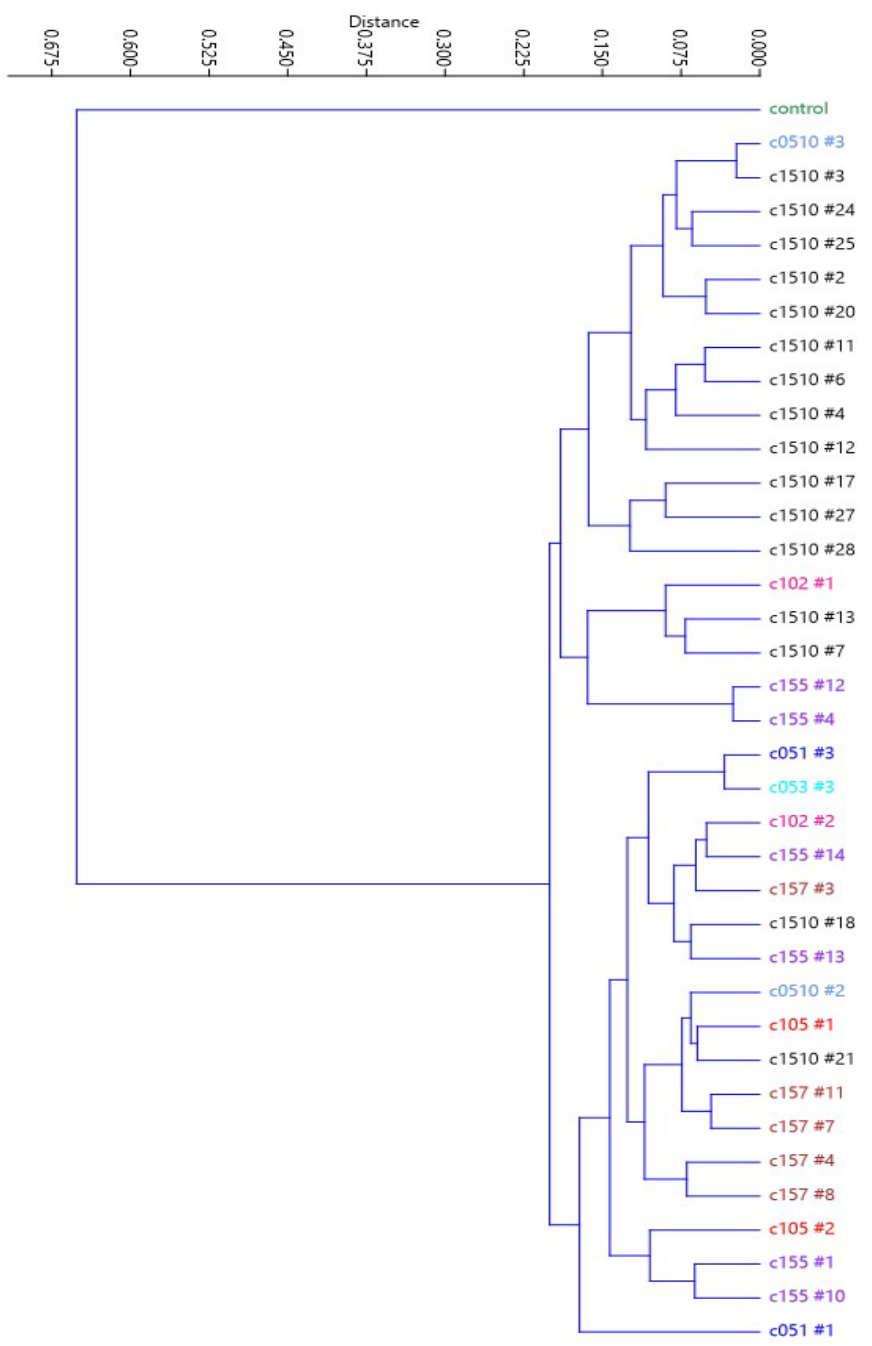

Fig. 9. The dendogram of colchiploid of Pontianak tangerine and control based on the cytological data

\section{Conclusion}

All colchiploid plants were aneuploid plants with chromosome number $18+x$. The colchiploid plants had a higher chromosome number, stomatal size, and chloroplast number than that of the control. The stomatal density in several genotypes did not differ from that of the control. The increasing of colchicine concentration and duration of treatment did not corelated with the increasing of ploidy number of colchiploid plants. The implication of the research result was the stomatal density, stomatal size, and chloroplast number were useful tools for rapid pre-screening of plant polyploidy. 


\section{References}

1. D. Agisimanto, F. Yulianti, Jurnal Iptek Holtikultura 31 (2016)

2. A. Manzoor, T. Ahmad, M.A. Bashir, I. A. Hafiz, C. Silvestri, Plants 8, 1 (2019)

3. T. Nukaya, M. Sudo, M. Yahata, Y. Nakajo, T. Ohta, K. Yasuda, A. Tominaga, H. Mukai, and H. Kunitake, Scientia Horticulturae 245, 210 (2019)

4. R. C. Verma, P. Dass, N. Shaikh, M. A. Khah, Chromosome Botany 12, 41 (2017)

5. J. H. Wu, A. R. Ferguson, B. G. Murray, Y. Jia, P. M. Datson, J. Zhang, Annals of Botany 109, 169 (2012)

6. J. Shao, C. Chen, X. Deng, Plant Cell, Tissue and Organ Culture 75, 241 (2003)

7. K. S. Kushwah, R. C. Verma, S. Patel, N. Jain, Journal of Phylogenetics \& Evolutionary Biology 06, (2018)

8. S. M. Miri, Journal of Plant Physiology and Breeding 10, 1 (2020)

9. U. Salma, S. Kundu, N. Mandal, Journal of Crop Science and Biotechnology 20, 9 (2017)

10. G. D. Ascough, J. Van Staden, J. E. Erwin, HortScience 43, 2248 (2008)

11. T. Arisuryanti, Rahmawati, A. K. Kartina, Buku Petunjuk Praktikum Analisis Sitogenetik Dan Karakterisasi Kromosom Tanaman (Gadjah Mada University Press, Yogyakarta, 2016)

12. L. Millstead, H. Jayakody, H. Patel, V. Kaura, P. R. Petrie, F. Tomasetig, M. Whitty, Frontiers in Plant Science 11, 1 (2020)

13. X. Qin and G. L. Rotino, Plant Cell, Tissue and Organ Culture 41, 145 (1995)

14. E. M. Torres, B. R. Williams, A. Amon, Genetics 179, 737 (2008)

15. B. Orr, K. M. Godek, D. Compton, Current Biology 25, R538 (2015)

16. G. Bhuvaneswari, R. Thirugnanasampandan, M. Gogulramnath, Physiology and Molecular Biology of Plants 26, 271 (2020)

17. W. H. Eng and W. S. Ho, Scientia Horticulturae 246, 604 (2019)

18. N. Moghbel, M. K. Borujeni, F. Bernard, Journal of Genetic Engineering and Biotechnology 13, 1 (2015)

19. D. Ewald, K. Ulrich, G. Naujoks, M. B. Schröder, Plant Cell, Tissue and Organ Culture 99, 353 (2009)

20. Z. Q. Tang, D. L. Chen, Z. J. Song, Y. C. He, D. T. Cai, Plant Cell, Tissue and Organ Culture 102, 213 (2010)

21. M. Abdoli, A. Moieni, H. Naghdi Badi, Acta Physiologiae Plantarum 35, 2075 (2013)

22. C. Xu, Z. Huang, T. Liao, Y. Li, and X. Kang, Plant Cell, Tissue and Organ Culture 125, $1(2016)$

23. D. H. Touchell, I. E. Palmer, T. G. Ranney, Frontiers in Plant Science 11, 1 (2020) 